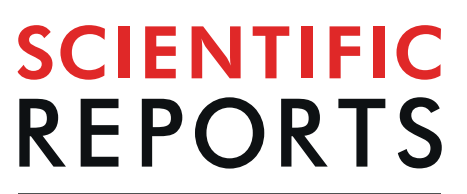

natureresearch

\title{
Anaphylaxis induced by Thalassophryne nattereri venom in mice is an IgE/lgG1-mediated, IL-4-dependent phenomenon
}

Fernanda Miriane Bruni, Erica Maria Martins Coutinho, Aline Ingrid Andrade-Barros, Lidiane Zito Grund, Monica Lopes-Ferreira \& Carla Lima*

We hypothesized that beyond the Thalassophryne nattereri venoms ability to induce in mice a strong specific-Th2 response with high levels of specific $\operatorname{lgE} / \mathrm{lgG1}$, it would be able to trigger anaphylaxis in sensitized individuals. To investigate whether the venom is capable of inducing an allergic reaction in mice and characterize soluble and cellular mediators involved in this process, BALB/c female mice were sensitized intraperitoneally with decreasing-dose of venom at weekly intervals for 4 weeks and challenged by intraperitoneal, oral or epicutaneous routes with venom 2 weeks later. Our data show that sensitized-mice challenged by all routes showed intense symptoms of anaphylaxis, dependent on the anaphylactic $\lg \mathrm{Gl}$ and $\mathrm{IgE}$ antibodies and mast cells. The late-phase reaction developed after initial symptoms was characterized by the influx of eosinophils, dependent on IL-5, IL-17A and eotaxin produced by Th2 cells in inflamed lungs and skin draining lymph-nodes. Using C57BL/6 deficient mice we demonstrated that IL-4 KO mice failed to develop anaphylactic symptoms or local Th2 inflammation, producing low levels of IgGI and increased levels of IgG2a. Together our results demonstrated that the venom of $T$. nattereri has allergenic proteins that can trigger an allergic process, a phenomenon IgEIgG1 dependent, IL-4-mediated and negatively regulated by IFN- $\gamma$.

Few studies have explored the mechanisms underlying allergy disorders triggered by venom from marine/aquatic organisms, other than the study that identified the venoms of anemone and jellyfish from the phylum Cnidaria as causing anaphylaxis in humans ${ }^{1}$.

Fish of toxicological importance are grouped into the venomous category, which present glands specialized in the secretion of venom and a specialized apparatus (spines with canals or canaliculated) for its inoculation ${ }^{2}$. Although accidents caused by these organisms have a low incidence due to their habitat and do not cause mortality in humans, they can cause serious accidents with varying degrees of morbidity for which there is no specific medicine ${ }^{3}$.

A growing number of accidents by the Thalassophryne nattereri toadfish has been reported among fishermen and bathers in the Brazilian coast (Fig. 1): Salvador ${ }^{4}$, Alagoas ${ }^{5}$, Fortaleza ${ }^{6}$, Natal and Para ${ }^{7}$; and toxicological, biochemical and pharmacological studies have been carried out by our group since $1998^{8}$. The venom apparatus of T. nattereri is composed of two dorsal and two lateral canaliculated spines covered by a membrane connected to venom glands at the base of the fins (Fig. 1B). When the spine penetrates the tissue of victims, the integumentary sheath enclosing the gland press out the venom into a duct and the venom is injected into the victim. According to Fonseca and Lopes-Ferreira ${ }^{4}$, the palm of the hands and the soles of the feet are the most commonly areas affected in humans (Fig. 1C).

The T. nattereri venom (VTn) causes pain, edema, erythema and necrosis that remain for a long time without an efficient healing process ${ }^{9}$. In addition, patients that suffer successive attacks have high IgG antibody (Ab) levels up to 6 months after injury ${ }^{10}$. As affected individuals of fishing communities tend to be poor and devoid of the necessary information and financial support to access health care, many cases go unreported. The envenoming represents a great cost to North and Northeast Brazilian communities in terms of public health (http://www. saude.gov.br; http://portalsinan.saude.gov.br). 
A)
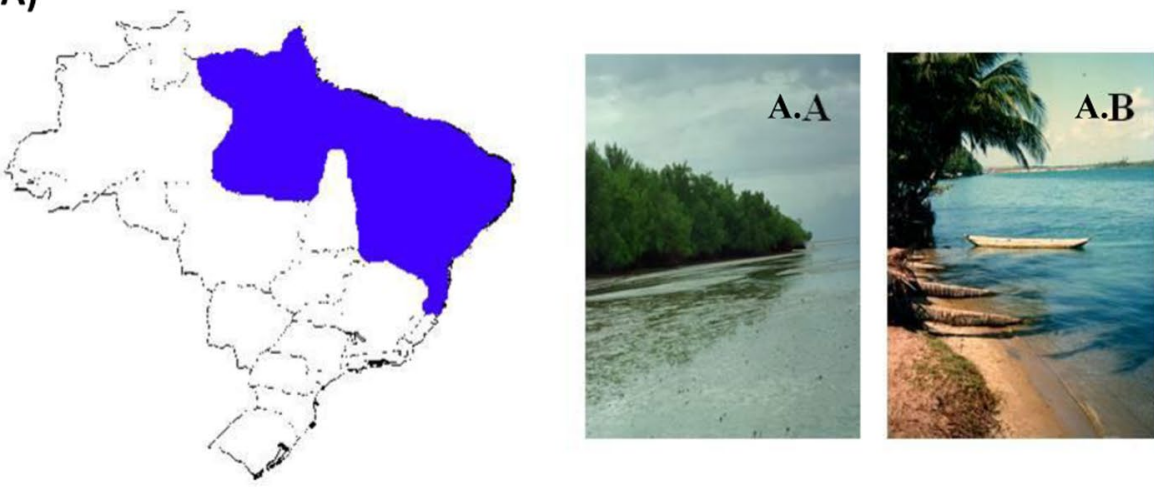

B)
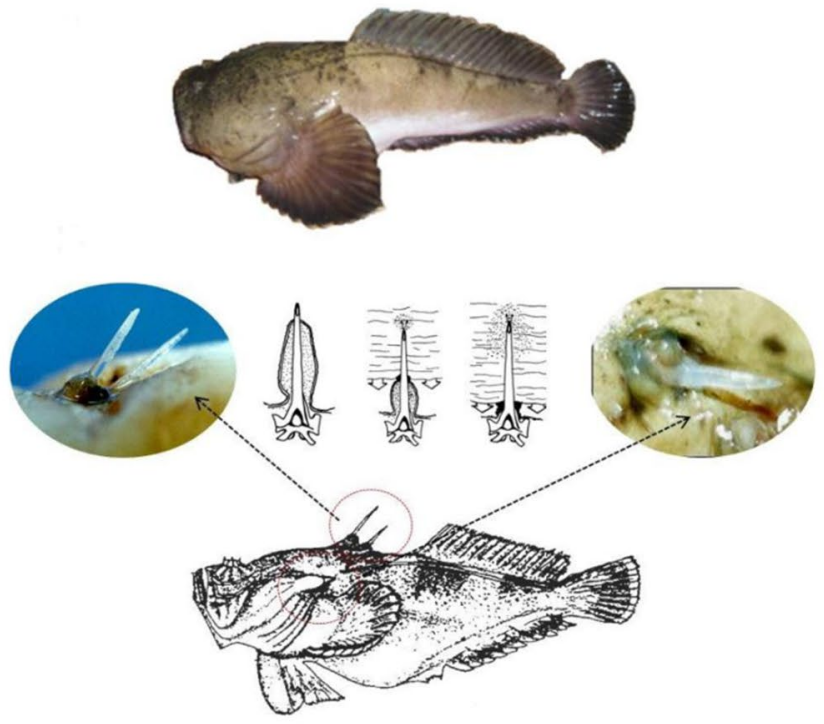

C)

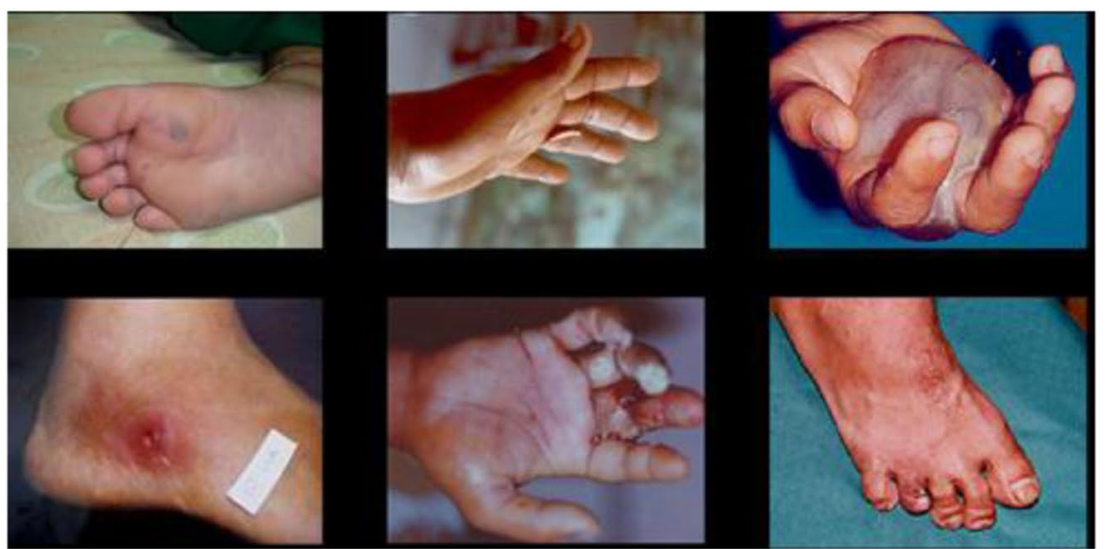

Figure 1. The T. nattereri is found predominantly in the states of the North and northeast regions of Brazil (in blue). In places such as Lagoa Mundaú (A.A) and Lagoa do Roteiro (A.B), both in Alagoas. T. nattereri has the most complete venom apparatus (B), consisting of four stings, two of which are located in the dorsal region (1st segment of the dorsal fin) in the median line, and two laterally placed above the pectoral fin in the opercular region. They all have communication with the venom glands. The inoculation of the venom occurs mainly in the palmar and plantar region and the injury in patients is characterized by pain, edema and necrosis difficult to heal (C). All images were taken by the co-author Dr. Monica Lopes-Ferreira.

Lopes-Ferreira et al. ${ }^{11}$ evidenced that low dose of venom $(0.3 \mu \mathrm{g} / \mathrm{mice})$, in injured tissue of mice, lead to an intense vascular congestion, stasis of blood flow in postcapillary venules and capillaries, beyond focal transient constrictions in arterioles. Curiously, low numbers of phagocytic cells during the first $24 \mathrm{~h}$ after VTn injection and the presence of necrotic material which had not been cleared out seven days after envenomation were described 
in injured tissues ${ }^{12}$. In addition, we observed a delayed influx of neutrophils to the injured site of venom-injected mice, arriving only after $24 \mathrm{~h}^{13}$.

The reproduction of T. nattereri envenoming in mice not only demonstrated a strong specific-Th2 immune response $\mathrm{e}^{14,15}$, but also a long-lasting humoral memory response with high levels of specific IgG1 and IgE Abs ${ }^{16}$. Moreover, we showed that Natterins, a family of proteases with kininogenase activity ${ }^{17}$ and the main components in the venom that trigger the toxic effects ${ }^{18}$ are responsible for the sustained $\mathrm{Th} 2$ humoral response in mice. Komegae et al. ${ }^{19}$ confirmed that the intraperitoneal immunization of BALB/c mice with proteolytically active Natterins induces a polarized Th2 response with elevated titers of anaphylactic specific-IgG1 and -IgE until 120 days. We also found that inactivation of protease activity abolished the ability of the Natterins to induce persistent production of specific-IgG1, total-IgE and mainly the production of anaphylactic Abs as IgG1 and IgE, favoring the development of specific Abs of the IgG2a subtype, characteristic of Th1 response ${ }^{19}$.

Thus, we hypothesized that the toxins of $T$. nattereri venom although immunogenic would also be capable of inducing an allergic process, characterized as chronic and Th2 mediated. Using a series of in vivo approaches, we subjected $\mathrm{BALB} / \mathrm{c}$ female mice to Th2 sensitization after several intraperitoneal injections of decreasing-dose of VTn with adjuvant followed by challenge with venom by different routes: local (peritoneal) or distal (nasal or epicutaneous). Thereafter C57BL/6 sufficient or deficient mice for some cytokines were used to evaluate the contribution of molecular pathways involved in venom hypersensitivity. Together our results show that the sensitized-mice with decreasing dose of venom developed: a) anaphylaxis with scores ranging from mild to severe, depending on challenge routes; b) produced anaphylactic IgG1 and IgE Abs; c) showed Natterins-specific IgG in the sera; d) recruited eosinophils and neutrophils to the lungs and to the skin later after decay of symptoms. The acute phase is triggered by PAF released after Natterins-IgE/IgG1 activation of mast cells; and the later reaction, mediated by IL-4 derived from CD4 T cells and antagonized by IFN- $\gamma$.

Our data in mice allow us to suggest that envenomated and consequently sensitized individuals with allergenic proteases of the T. nattereri fish venom when re-exposed to the venom can develop symptoms of anaphylaxis with eosinophilic inflammation in the lungs and in the skin, a process IgE/Th2 mediated.

\section{Results and Discussion}

The venom of $T$. nattereri Brazilian fish triggers anaphylaxis in mice dependent on mast cell derived-molecules. Clinical observations show that fishermen repeatedly injured with T. nattereri develop urticariform reactions in their arms and legs accompanied by wheezing and rhinitis (personal communications). Experimental data from our group demonstrated that fish venom induces in mice a humoral immune response characterized by elevated levels of IL- 5 and IgE Abs. Thus, we hypothesized that the toxins of T. nattereri venom although immunogenic would also be capable of inducing an allergic process, characterized as chronic and Th2 mediated.

The aim of this study was to investigate the capacity of the venom of T. nattereri to induce an allergic process in mice. We sought to develop a murine model of acute systemic hypersensitivity reaction to identify the involvement of individual cellular components and soluble mediators decisive in the induction of the emergence of anaphylaxis symptoms, and also, the development of the late-phase inflammatory reaction in the skin and respiratory tract.

The development of murine models of anaphylaxis that mimic the physiological and immunological characteristics of human anaphylaxis has facilitated the understanding of the underlying mechanisms of both phases of allergic immune response. The different models developed for different types of allergens differ not only in the type of allergen used, but also in the protocol of sensitization including different doses and in the parameters applied to the evaluation of the sensitization. In particular, some models of allergen sensitization use intraperitoneal via in the presence of adjuvants ${ }^{20}$ or adjuvant-free ${ }^{21}$, oral immunization with the mucosal adjuvant cholera toxin $^{22,23}$, and more, intranasal or epicutaneous sensitization with or without the use of adjuvants ${ }^{24,25}$. Some model requires multiple sensitizations ${ }^{26}$ or a single sensitization ${ }^{27}$.

Here, we subjected $\mathrm{BALB} / \mathrm{c}$ female mice to Th2 sensitization after repeated intraperitoneal injections of decreasing-dose of VTn with adjuvant (only at day 0 ) followed by challenge with venom by different routes: local (peritoneal) or distal (nasal or epicutaneous) (Fig. 2A). As demonstrated in Fig. 2B, VTn sensitized-mice challenged by i.p. or i.n. (a single nasal instillation) injections of venom presented clinical symptoms of anaphylaxis within a few minutes after challenge. The continuous licking or scratching of the mouth and ear with paws observed after both challenges (score 1) were followed after $10 \mathrm{~min}$ by wheezing and cyanosis around the mouth and the tail in mice challenged by intraperitoneal route (score 3). Control-mice challenged only with saline did not develop symptoms of anaphylaxis.

The symptoms of the acute phase are dependent on mediators released after degranulation of mast cells activated by cross-linking of FceRI-bound IgE with antigen ${ }^{28}$. Next we figure out the role of the preformed molecules contained in the mast cell granules as histamine, and PAF (platelet-activating factor) the newly synthesized lipid derivative ${ }^{29}$, in the control of anaphylactic symptoms induced by VTn. By both route of challenge, VTn induced the production and release of histamine, especially by intraperitoneal challenge (Fig. 2C). The anaphylactic symptoms induced by VTn were completed inhibited when active PAF receptor was blocked by the selective antagonist ABT-491 (Fig. 2D), but the blocking of PAF receptor did not inhibit the late-phase intraperitoneal inflammation neither the production of anaphylactic IgG1 (data not shown). Together these results allow us to conclude that the T. nattereri venom has allergenic proteins capable of triggering IgE/mast cell-mediated anaphylaxis.

The early-phase response is characterized by anaphylactic Abs production. Sensitization elicits a Th2-cell response, in which IL-4 and IL-13 drive allergen-specific IgE Abs in humans (and IgE and IgG1 in mice) that binding to the FceRI molecules on a single mast cell. In mice, IgG1 binds only to Fc $\gamma$ RIIB and Fc $\gamma$ RIII, and 
A)

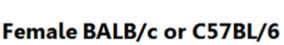

VTn Challenge

Analysis

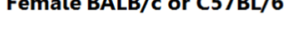

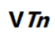

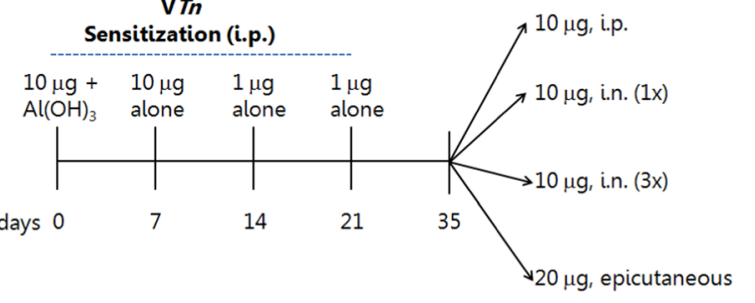

(anaphylaxis and late-phase response)

B)

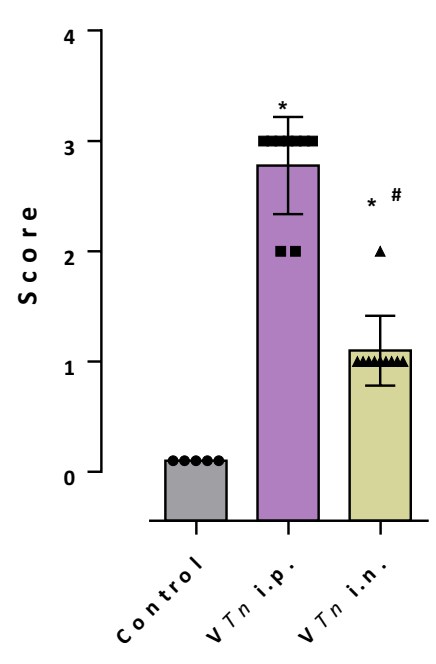

C)

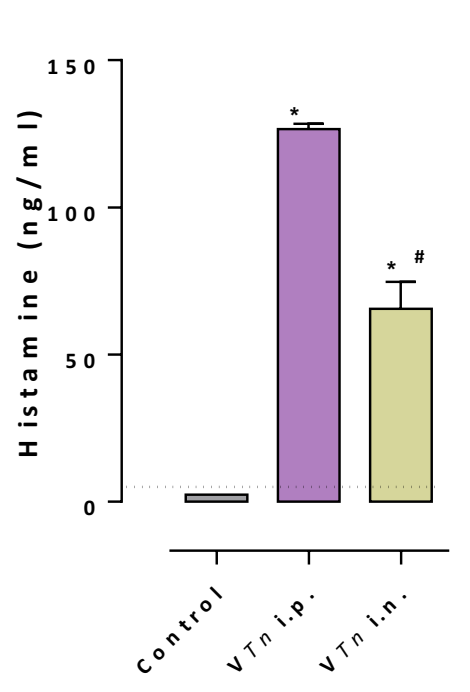

)
$48 \mathrm{~h}$

$72 \mathrm{~h}$

$24 \mathrm{~h}$

$48 \mathrm{~h}$

D)

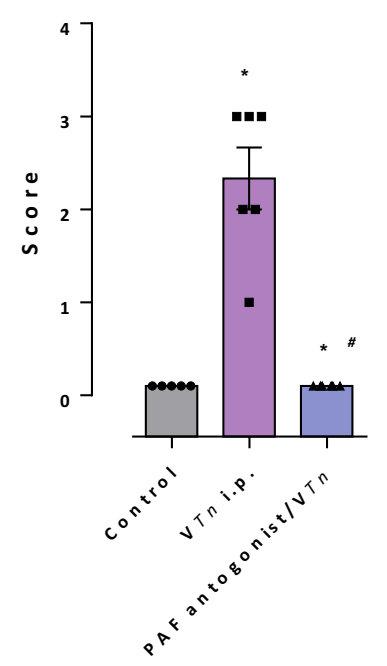

Figure 2. The venom of T. nattereri Brazilian fish triggers anaphylaxis in mice dependent on mast cell derived-molecules. Female BALB/c mice immunized by the i.p. injection of $10 \mu \mathrm{g}$ of venom adsorbed in $1.6 \mathrm{mg}$ of aluminum hydroxide on day 0 were boosted $7(10 \mu \mathrm{g}), 21$ and $28(1 \mu \mathrm{g})$ days later. At day 35, mice were challenged by a single i.p. or i.n. injection or by multiple i.n. instillations. Mice previously shaved and scratched, with hypoallergenic dermal tapes embedded in venom solution (A). Twenty-four hours, 48 or $72 \mathrm{~h}$ after the last challenge, the symptoms of anaphylaxis were scored $(\mathbf{B}, \mathbf{D})$ and the levels of histamine were measured in the supernatant of peritoneal exudates $(\mathbf{C})$. The results represent the mean \pm SEM of 5 animals/group. The dashed line represents the detection threshold. ${ }^{*} \mathrm{p}<0.05$ compared with control-group; ${ }^{*} \mathrm{p}<0.05$ compared to intraperitoneal challenged-mice. 
produced in a Th2 allergic context in mice is responsible for the passive cutaneous anaphylaxis and systemic anaphylactic response $\mathrm{e}^{30-32}$. Next, we evaluated the capacity to distinct routes of VTn challenge to induce anaphylactic Abs production in plasma of sensitized-mice by the evaluation of VTn-specific Abs using ELISA or PCA assays.

In Fig. 3 we observe that all route of VTn re-exposition induced in sensitized-mice high concentrations of specific IgG1 and low levels of IgG2a Abs (Fig. 3A). Epicutaneous challenge was ineffective to induce IgG2a Abs production in sensitized mice, producing only specific IgG1. For PCA in mice (IgG1) and in rats (IgE, Fig. 3B), we found that the re-exposition of sensitized-mice to VTn by all route of challenge induced the production of low titers of anaphylactic IgG1 Abs as well as high titer of IgE after i.p. challenge (Fig. 3C). Plasma of mice from the control-group was negative for anaphylactic antibodies.

The allergenic proteases already described in the literature show differences regarding their structure, specificity of the binding site, the class to which they belong and the source of origin. However, there is a consensus that its ability to induce IgE synthesis is related to its proteolytic capacity. Studies in mice confirm that proteolytically active allergens have the ability to induce IgE and IgG1 anaphylactic Abs synthesis that drive allergic response ${ }^{33-38}$. The literature on the protease derived from allergens is extensive, and its role for development of Th2 polarized responses is well established. Next, we confirmed that Natterins were recognized by both sera from $V T$ n-sensitized mice and from pool of seven T. nattereri human victims (red dotted square, Fig. 3D), demonstrating that after envenoming the production of anaphylactic specific-IgE and IgG1 antibodies is dependent on Natterins.

The late-phase response induced by $T$. nattereri venom is characterized by leukocytes influx. After the end of the symptoms of the acute anaphylactic reaction and a period without symptoms, allergic individuals present a new inflammatory condition characterized by the accumulation of Th2 lymphocytes and mainly of eosinophils in skin, lung, or nose (depending on the site of challenge), a period denominated as the late-phase response ${ }^{39}$. Then, we evaluated the cellular profile of the late-phase response generated by the $T$. nattereri venom sensitization.

Our results depicted in Fig. 4A show that the VTn intraperitoneal challenge promoted after $48 \mathrm{~h}$ in peritoneal cavities of sensitized-mice an accumulation of leukocytes mainly eosinophils as demonstrated by the analysis of CCR3 expression gated cells or by photomicrographs of slides with H\&E stained peritoneal cells. The leukocyte influx induced into the peritoneal cavities after 35 days of VTn sensitization was characterized by a mixed inflammatory phenotype during the chronic phase with the presence of macrophages (4-fold) and mainly eosinophils (54-fold) and neutrophils (23-fold) (Fig. 4B), recapitulating one of the hallmarks of severe allergic inflammatory diseases, including cellular infiltration by both eosinophils and neutrophils ${ }^{40,41}$. In control-mice, neutrophils and eosinophils were barely detectable, and resident macrophages were the major myeloid cells in the peritoneal cavities.

Next, we evaluated the levels of the important cytokines and chemokines that drive the development of allergic late-phase reaction. These mediators were evaluated in supernatants of peritoneal exudates by cytokine-specific ELISA (Fig. 4C). We observed that i.p. challenge promoted the release of IL-5 (2.6-fold), an important cytokine responsible for promoting the growth, differentiation and maturation of eosinophils in the bone marrow ${ }^{42}$, the release of IL-17A (4-fold), responsible for the recruitment and survival of neutrophils and macrophages ${ }^{43,44}$; and eotaxin (4-fold), which during the course of the inflammatory response, together with IL-5 promotes the rapid expansion of eosinophilic progenitors in the bone marrow and, subsequently, terminal differentiation in mature eosinophils and migration through the bloodstream to the inflamed tissue ${ }^{45}$. No significant levels of the IL-4, IL-13, IL-10 or IFN- $\gamma$ were detected in the supernatants of peritoneal exudates of i.p. VTn challenged-mice.

Together these results show that sensitization and intraperitoneal challenge with the venom of T. nattereri promote an allergic response characterized by mast cell-dependent acute phase of anaphylaxis followed by the influx of eosinophils to the challenge site guided by Th2 cytokines.

The airway allergic response triggered by venom. Next, we evaluated whether the exposition of intraperitoneal sensitized-mice to nasal instillation of VTn could also triggered an allergic inflammatory response in the lungs as demonstrated by Arizmendi et $a l .^{25}$. For then, group of i.p. sensitized-mice exposed to 3 consecutive nasal instillations was evaluated after $24 \mathrm{~h}$ of the last challenge (Fig. 5).

We observe that the consecutive nasal instillations triggered the passage of a large number of eosinophils through the bloodstream to the pulmonary interstitium accumulating predominantly in the perivascular and peribronchial regions of lung tissues (Fig. 5A), and then to the bronchoalveolar space (almost 5-fold in relation to the control, Fig. 5B). In contrast, lung sections from control-mice showed almost normal histology, with marginal perivascular and peribronchiolar lymphocytic infiltrate (Fig. 5A,B).

By flow cytometry, we confirmed that the consecutive three nasal instillations of VTn in sensitized-mice generated the differentiation with the consequent migration to the lungs of IL-5-producing (2.3-fold), IL-4-producing (1.6-fold), IL-17A-producing (2.5-fold) CD4 T-lymphocytes, as well IFN- $\gamma$-producing (2-fold) CD4 T-lymphocytes, compared to control-mice (Fig. 5C).

These results confirm that the repeated exposure of the respiratory tract of mice sensitized with T. nattereri venom generates a weak anaphylactic response with mild symptoms, but is capable of triggering a late phase of inflammatory reaction in the lungs. The pulmonary eosinophilic inflammation triggered by airway exposure to VTn is also characterized by the influx of CD4 Th2 lymphocytes in the lung.

The epicutaneous exposure to the VTn triggers inflammation. In addition to a localized reaction in the lungs, atopic individuals may present in response to dermal exposure pruriginous urticariform reactions with edema $^{24,46,47}$. For assessment of the development of an allergic skin response, VTn sensitized-mice by the i.p. route 
A)

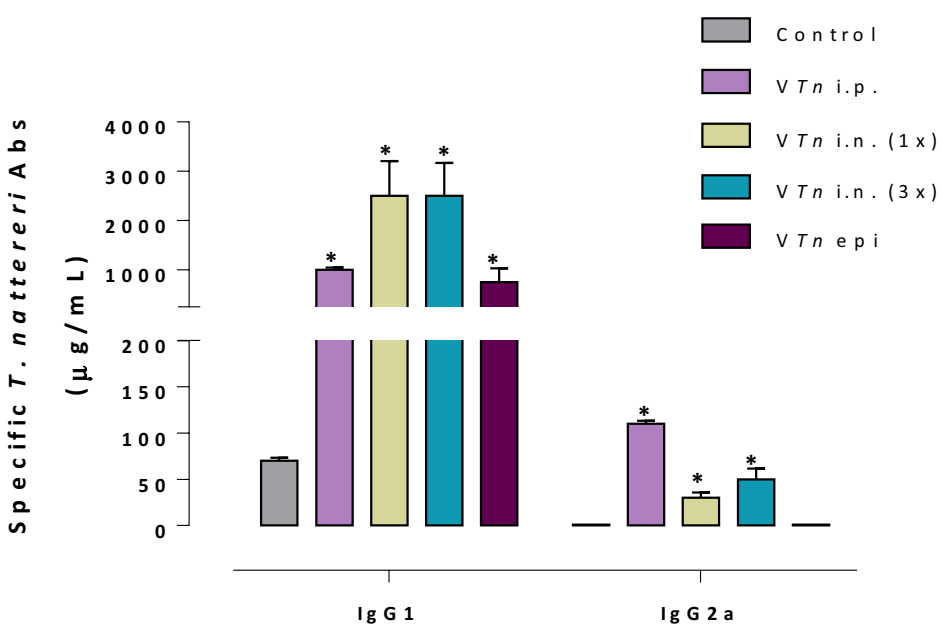

B)

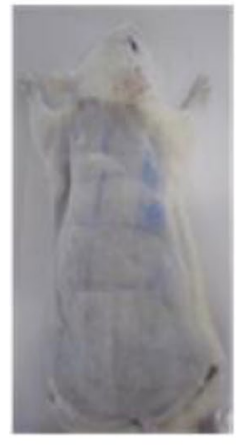

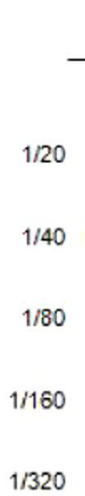

$1 / 20$
$1 / 40$
$1 / 80$
160
1320

IgE (PCA titer)

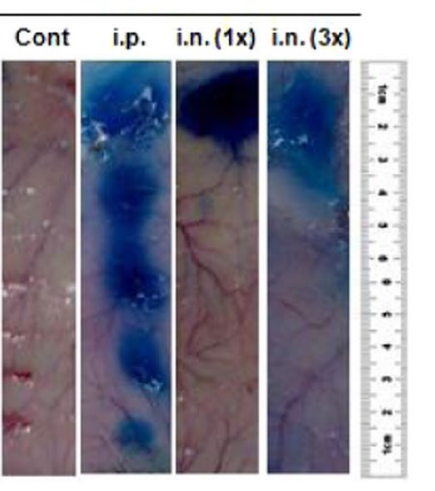

D)

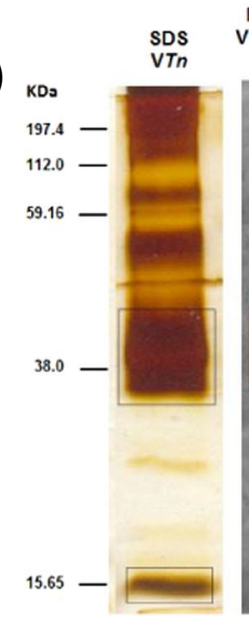

Plasma from Plasma from VTn-sensitized Human mice patient
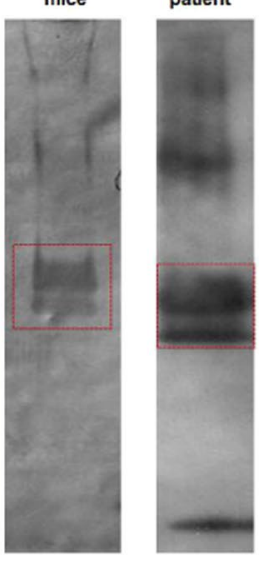

\section{C)}

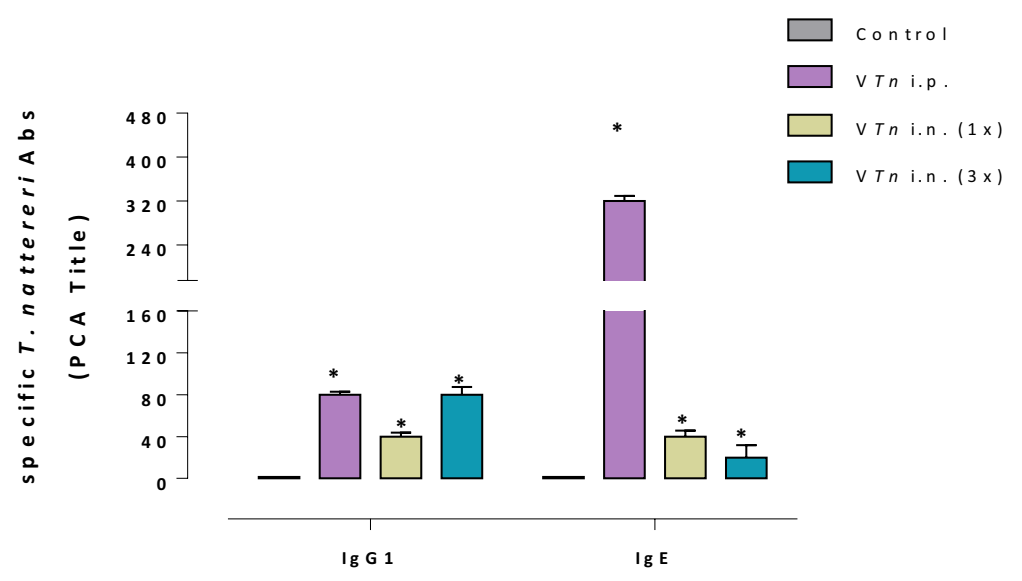

Figure 3. The early-phase response is characterized by anaphylactic Abs production. After the last challenge, the levels of venom specific-IgG1 and IgG2a were determined by ELISA in plasma of BALB/c sensitizedmice (A); and the titers of anaphylactic specific VTn-IgG1 in mouse and specific VTn-IgE in rats (B) were determined by PCA $(\mathbf{B}, \mathbf{C})$. The PCA titer represents the highest dilution of pooled plasma that gave a positive reaction (diameter $>5 \mathrm{~mm}$ ). VTn was fractionated by SDS-PAGE and proteins were transferred to nitrocellulose membrane that was incubaedt with pool of plasma from allergic mice diluted 1:20 and revealed with goat antimouse IgG. Numbers on the left correspond to molecular mass markers (D). The results represent the mean \pm SEM of 5 animals/group. The dashed line represents the detection threshold. $* p<0.05$ compared with controlgroup. 
A)
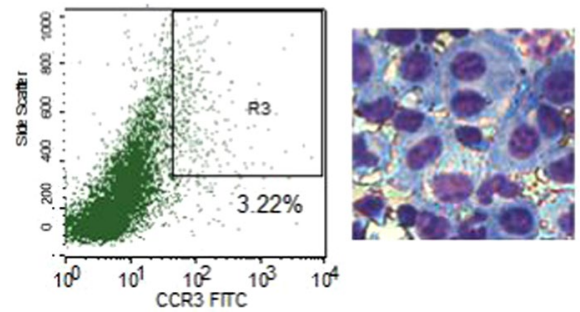

Control
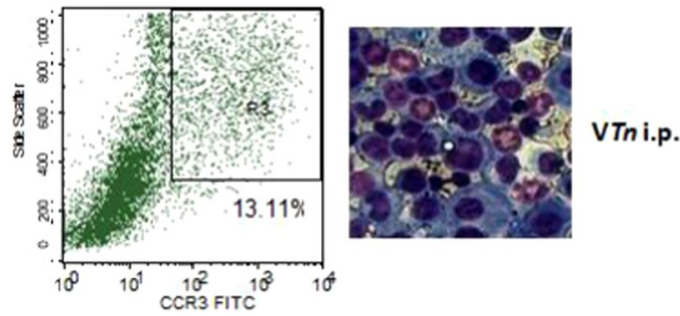

B)

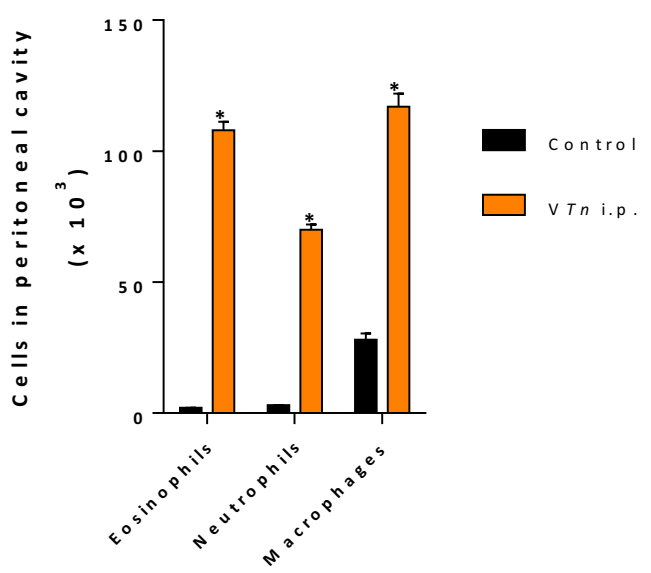

C)

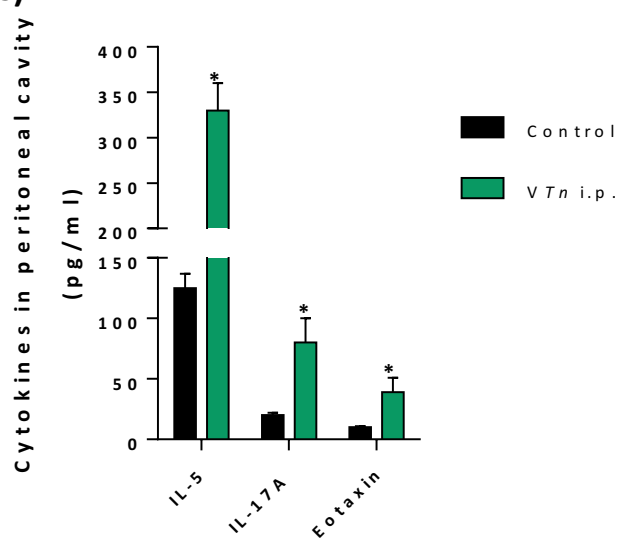

Figure 4. The late-phase response induced by T. nattereri venom is characterized by leukocytes influx. After $48 \mathrm{~h}$ of intraperitoneal challenge, the influx of eosinophils to exudates of peritoneal cavities of BALB/c sensitized-mice was phenotypically monitored by flow cytometry based on CCR3 membrane expression and morphologically by H\&E staining (A). The differential cell count (B) and the levels of cytokines in exudates of peritoneal cavities (C) were also evaluated. The results represent the mean \pm SEM of 5 animals/group. *p $<0.05$ compared with control-group.

were challenged on the day 35 by the epicutaneous via with the fixation on the back of hypoallergenic dermal tape embedded with venom (Fig. 2A). After $48 \mathrm{~h}$ of challenge, mice were bled and killed to obtain blood, skin and draining lymph nodes. It was not possible to quantify the anaphylactic symptoms triggered by the epicutaneous exposure of the venom since for the observation of the lesions mice were kept anesthetized. 
A)
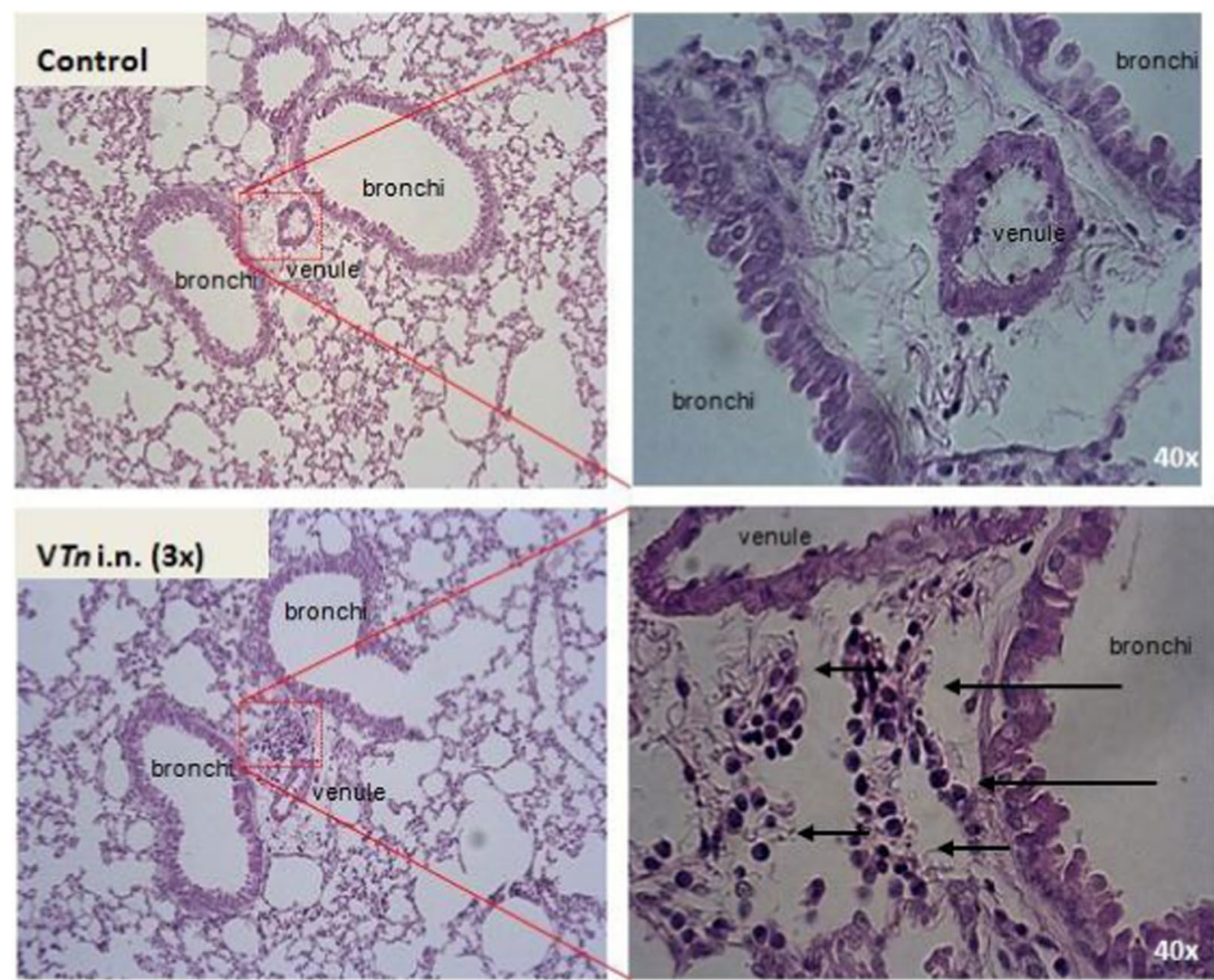

B)

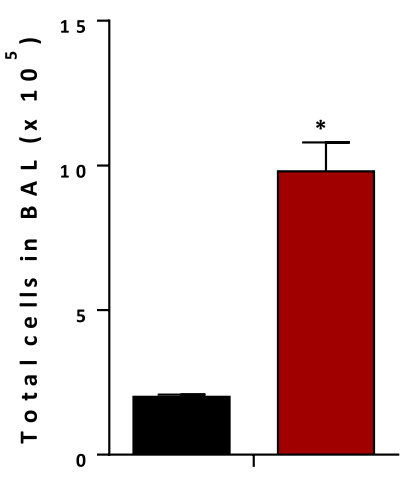

C)

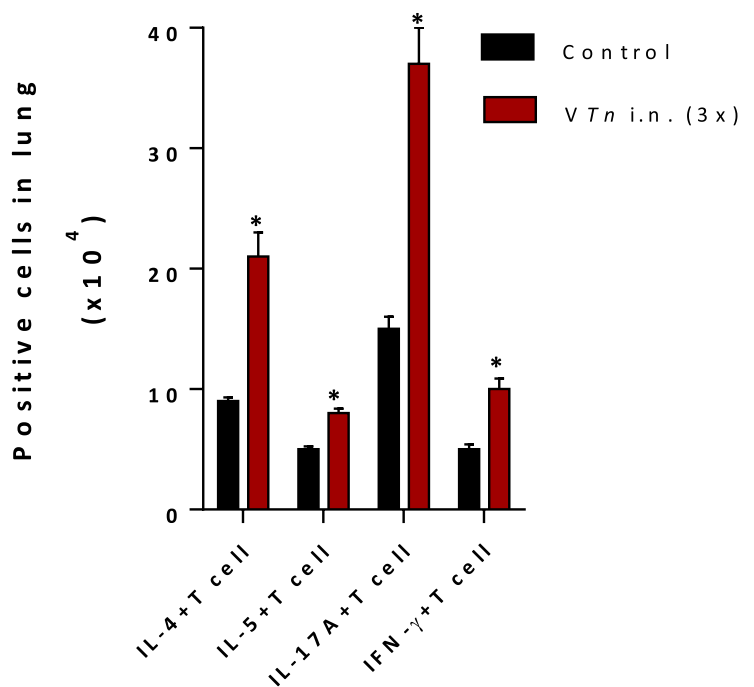

Figure 5. The airway allergic response triggered by venom. Lung sections stained with H\&E (A) show normal morphology or cellularity in control-mice (upper) and perivascular and peribronchiolar eosinophils and neutrophils were observed in BALB/c sensitized-mice (bottom). The total number of leukocytes in BAL (B) and cytokine-producing CD4 T cells in supernatant of re-stimulated lung cell suspension were determined by flow cytometry $(\mathbf{C})$. The results represent the mean \pm SEM of 5 animals/group. ${ }^{*} \mathrm{p}<0.05$ compared with control-group.

Mast cells are been demonstrated develop a critical role in neurogenic inflammation leading to pain and itch $^{48,49}$. The histological analysis of skin sections stained with $\mathrm{H} \& \mathrm{E}$ and the quantification of the number of cells in a section of $400 \mathrm{~mm}^{2}$ per slide revealed a dermatitis with edema (Fig. 6A) and infiltration of inflammatory cells in the subcutaneous region (Fig. 6B), consisting primarily of mononuclear cells, eosinophils, and toluidine blue-positive mast cells as demonstrated in the red square. 


\section{A)}
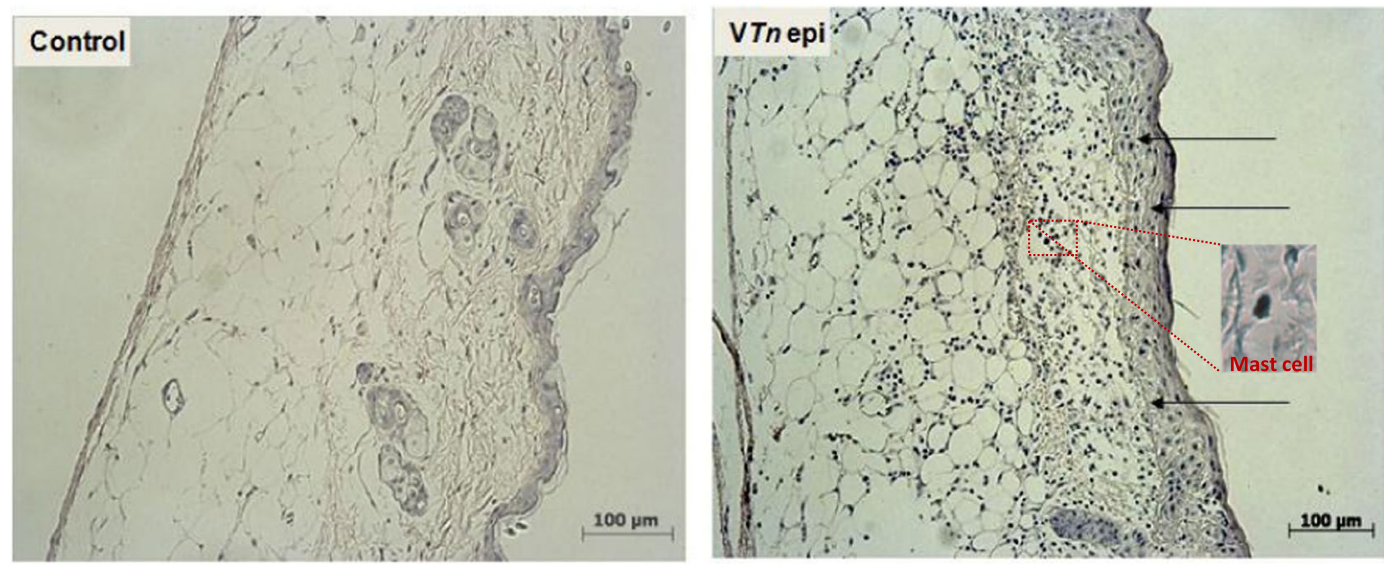

B)

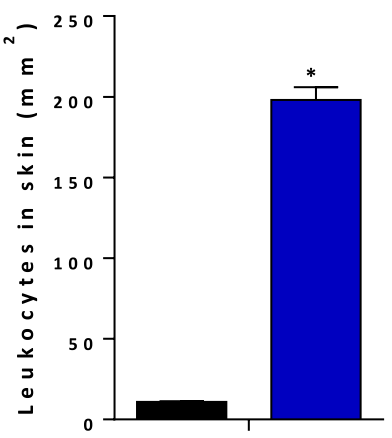

C)

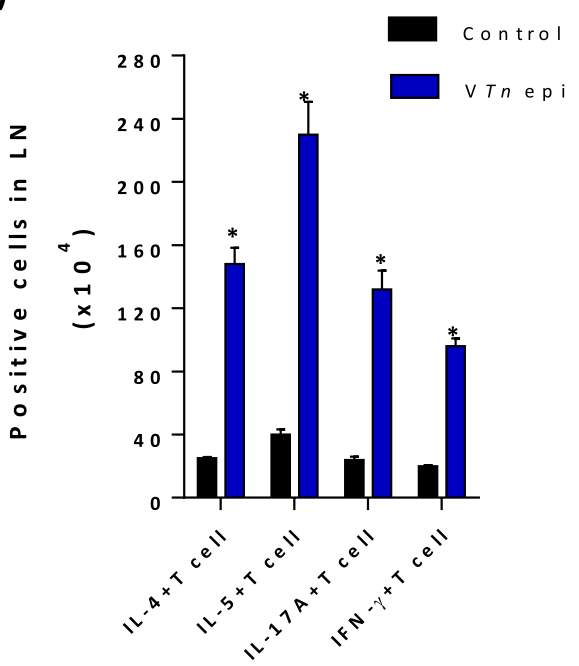

Figure 6. The epicutaneous exposure to the VTn triggers skin inflammation. BALB/c sensitized-mice challenged with epicutaneous exposure had the skin removed for staining with $\mathrm{H} \& \mathrm{E}$ or toluidine blue. Black arrows indicate leukocyte influx into the subcutaneous region of the dermis. Edema and toluidine blue-positivemast cell (square) are observed in venom exposed mice (right) in relation to the control-mice (left). The total number of leukocytes in draining lymph nodes cell (B) and cytokine-producing CD4 T cells in the supernatant of re-stimulated cell suspension were determined by flow cytometry $(\mathbf{C})$. The results represent the mean \pm SEM of 5 animals/group. *p $<0.05$ compared with control-group.

In the draining lymph nodes of mice exposed to epicutaneous challenge, we observed the presence of mainly IL-5- and IL-4-producing CD4 T-lymphocytes (6-fold) compared with control-group, followed by IL-17A-producing T cells (5.5-fold) and also by IFN- $\gamma$-producing T cells (4.8-fold) (Fig. 6C).

These results confirm that the exposure of the skin of mice sensitized with T. nattereri venom triggers dermatitis with edema and subcutaneous infiltration of CD4 Th2 lymphocytes that drive leukocytes influx.

Modulation of the acute symptoms and the late-phase of inflammatory reaction induced by $T$. nattereri venom. The biphasic hypersensitivity reaction is a systemic disorder dependent on an antigen-specific IgE and cytokines as IL-3, IL-4, IL-5, IL-9 and IL-13 produced by Th2 cells. To confirm the role of these cytokines in the development and maintenance of the allergic process induced by the VTn, C57BL/6 IL-4-, IFN- $\gamma$ - or IL-12-deficient mice were used for sensitization and challenge by intraperitoneal route (Fig. 7A).

In the Fig. 7B we observed that the challenge with the venom of sensitized C57BL/6 WT mice triggered the onset of anaphylactic symptoms of score 1, compared to the normal control-mice. Deficiency in the IL- 4 in mice abolished the ability of the venom to induce mild anaphylactic symptoms, but in contrast, mice deficient in the IFN- $\gamma$ or IL-12 had an increased anaphylactic symptoms with score 2 and score 3, respectively. Next, the supernatants of peritoneal exudates of $W T$ or $K O$ mice were evaluated for histamine (Fig. 7C). After i.p. challenge of WT sensitized-mice we notice the presence of high levels of histamine in response to VTn challenge compared with control-mice (dotted line). However, after i.p. VTn challenge of IL-4 KO or IL-12 KO sensitized-mice the levels of histamine reduced 2-times compared to WTVTn sensitized and challenged-mice. In contrast, no alteration in the 
A)

B6 $W T \times K O$

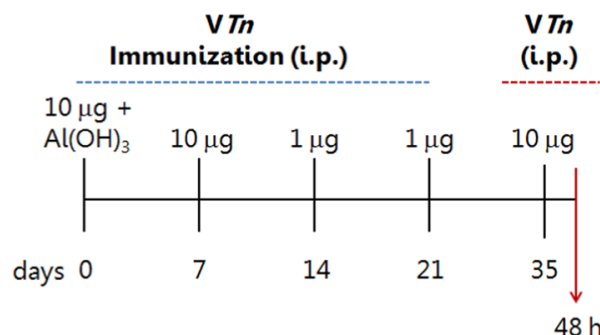

Analysis

B)

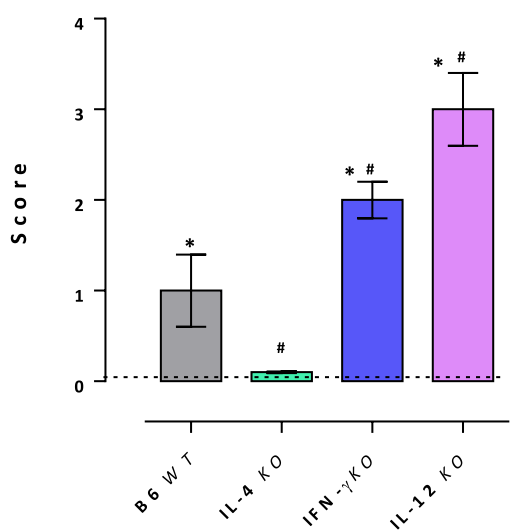

D)

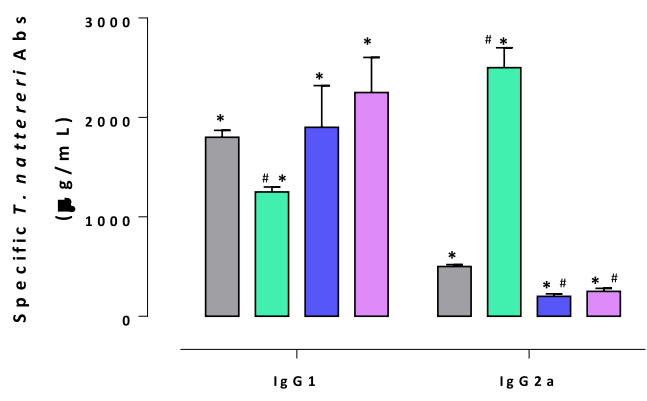

C)

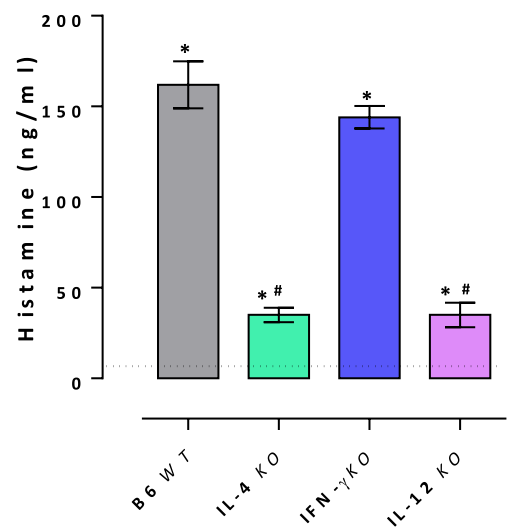

E)

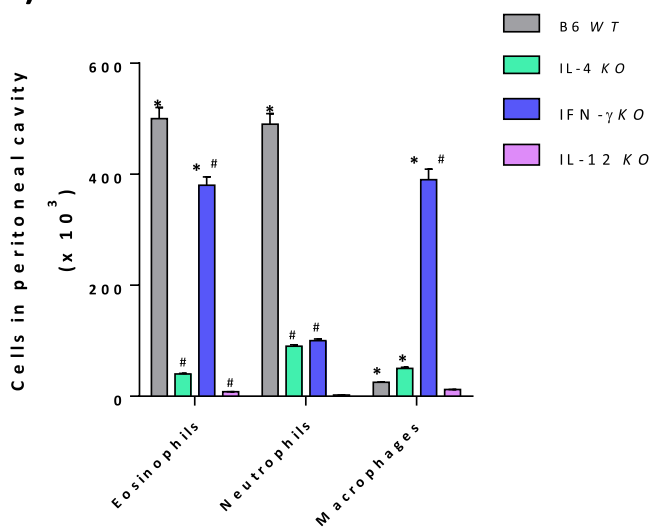

Figure 7. Modulation of the acute symptoms and the late-phase of inflammatory reaction induced by $T$. nattereri venom. Female C57BL/6 WT or IL-4 KO, IFN- $\gamma$ KO or IL-12 KO i.p. sensitized-mice were challenge by i.p. route and $48 \mathrm{~h}$ later (A) the symptoms of anaphylaxis were scored (B), the levels of histamine were measured in the supernatant of peritoneal exudates (C); and the plasmatic levels of venom specific-IgG1 and IgG2a were determined by ELISA and PCA (D). The PCA titer represents the highest dilution of pooled plasma that gave a positive reaction (diameter $>5 \mathrm{~mm}$ ). The total number of leukocytes in exudates of peritoneal cavities was also evaluated (E). The results represent the mean \pm SEM of 5 animals/group. The dashed line represents the detection threshold. ${ }^{*} \mathrm{p}<0.05$ compared with control-group; ${ }^{*} \mathrm{p}<0.05$ compared to VTn-challenged-WT mice.

level of histamine was observed in IFN- $\gamma$ KO mice ( $W T: 162 \pm 13$ vs KO: $144 \pm 6.2$ ). Together these results show that the mild symptoms of anaphylaxis in C57BL/6 induced by VTn are positively regulated by IL-4 and IL-12, and negatively regulated by IFN- $\gamma$.

IL-4 produced by Th2 lymphocytes modulates various characteristics of the allergic response such as eosin-

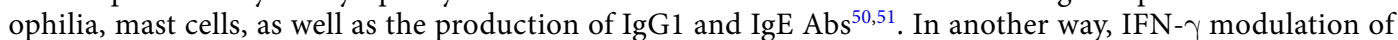
IgG2a production is the hallmark of the Th1 humoral response ${ }^{52}$. Our results presented in Fig. 7D show that C57BL/6 WT VTn-sensitized and challenged mice produced a robust IgG1 specific response and low levels of IgG2a. However, the deficiency of IL-4 resulted in slight decrease of IgG1 production and instead enhanced IgG2a production. The absence of IFN- $\gamma$ did not alter the IgG1 production, but drastically decreased IgG2a synthesis, 
compared to the VTn challenged C57BL/6 WT mice. Also, IL-12 deficiency did not alter the large amount of IgG1 induced by venom and promoted a decrease in IgG2a synthesis. Together, we observe that IL-4 positively regulates IgG1 Abs production and the positive control in the synthesis of IgG2a is coordinated by IFN- $\gamma$ and IL- 12 .

Finally, the results presented in Fig. 7E show that the significant recruitment of leukocytes into the peritoneal cavity of VTn sensitized and challenged-WT mice was characterized by the influx of few macrophages and mainly high number of eosinophils and neutrophils. However, the functional absence of IL- 4 or IL-12 promoted a strong decrease in eosinophils and neutrophils into the peritoneal cavity of the $K O$ mice challenged with the venom and, in contrast, the absence of IFN- $\gamma$ promoted a partial reduction in the influx of eosinophils and strong reduction in the number of neutrophils recruited to the peritoneal cavities in response to venom.

The positive regulation by IL- 4 and IL- 12 of the mixed inflammatory phenotype during the chronic phase of $V T n$ response is corroborated by others that show Th1 cytokines as coadjuvants in the maintenance and exacerbation of allergic manifestations ${ }^{53,54}$. A positive correlation was found between the high levels of IL-12 and the state of activation of Th2 lymphocytes in atopic children with dermatitis ${ }^{55}$. Moreover, Zhang and co-workers ${ }^{56}$ found IL-12 is able to induce IL- 4 synthesis by mast cells via Akt/ERK.

This is the first study that describes the induction of anaphylactic reaction by Thalassophryne nattereri toadfish venom accompanied by a detailed characterization of the various cellular and soluble mediators involved in this process. Our results allow us to conclude that the venom has allergenic proteins likely Natterins capable of triggering the allergic process in mice, characterized by IgE-mediated anaphylaxis and Th2 cytokine dependent late-phase eosinophilic inflammation. In addition, our data confirm that T. nattereri venom-induced anaphylaxis in sensitized-mice is an IgE/IgG1-mediated, IL-4-dependent phenomenon produced by allergen-specific Th2 lymphocytes and negatively regulated by IFN- $\gamma$. Finally, we observed a positive participation of IL- 12 in the induction of localized inflammatory exacerbation, controlling together with IL-4 the influx of eosinophils and neutrophils.

The establishment of a murine model of anaphylaxis induced by T. nattereri fish venom represents a progress, since elucidates the cellular and molecular mechanisms of the allergic reaction and becomes a valid proof for proposing therapeutic intervention to prevent and treat allergic episodes in human victims.

\section{Material and Methods}

Mice. The study with mice and rats was carried out accordance with the recommendations in the Guide for the Care and Use of Laboratory Animals of the Brazilian College of Animal Experimentation and was approved by the Committee on the Ethics of Animal Experiments of the Butantan Institute (Permit Number: 552/08) and of University of São Paulo (Permit Number: 60/70/2). All surgery was performed under sodium pentobarbital anesthesia, and all efforts were made to minimize suffering. Female BALB/c mice (5-6 weeks old) were obtained from a colony at the Butantan Institute, São Paulo, Brazil. Female C57BL/6 wild type (WT), C57BL/6 IL-4 knockout $(K O)$, IFN- $\gamma \mathrm{KO}$, and IL-12 KO mice were obtained from a colony at Institute of Biomedical Sciences II, University of Sao Paulo, Sao Paulo, Brazil. Animals were housed in a laminar flow holding unit (Gelman Sciences, Sydney, Australia) in autoclaved cages on autoclaved bedding, in an air-conditioned room in a $12 \mathrm{~h}$ light/dark cycle. Irradiated food and acidified water were provided ad libitum.

Thalassophryne nattereri venom. All necessary permits for T. nattereri capture, conservation and venom collection were approved by the IBAMA (Instituto Brasileiro do Meio Ambiente e dos Recursos Naturais Renováveis, Permit Number: 14693-1). T. nattereri fish venom (VTn) was obtained from fresh captured specimens at the Mundau Lake in Alagoas, state of Brazil with a trawl net from the muddy bottom of lake. No protected specimens were captured and fish were transported to Immunoregulation Unit of Butantan Institute. Venom was immediately extracted from the openings at the tip of the spines by applying pressure at their bases. After centrifugation, venom was pooled and stored at $-80^{\circ} \mathrm{C}$ before use. Endotoxin content was evaluated (resulting in a total dose $<0.8 \mathrm{pg} / \mathrm{mL}$ LPS) with QCL-1000 chromogenic Limulus amoebocyte lysate assay (Bio-Whittaker) according to the manufacturer's instructions. After that fish were anesthetized with 2-phenoxyethanol prior to sacrifice by decapitation.

Sensitization and challenge by $T$. nattereri venom. Groups of 5 mice were immunized with intraperitoneal (i.p.) injections of $10 \mu \mathrm{g}$ of VTn plus $1.6 \mathrm{mg}$ of aluminum hydroxide $\left(\mathrm{Al}(\mathrm{OH})_{3}\right.$, Pepsamar, Sanofi-Synthelabo SA, Rio de Janeiro, Brazil) in $500 \mu \mathrm{L}$ of PBS on day 0 , and boosted only with VTn on days $7(10 \mu \mathrm{g}$ in $500 \mu \mathrm{L}), 14$ $(1 \mu \mathrm{g}$ in $500 \mu \mathrm{L})$ and $21(1 \mu \mathrm{g}$ in $500 \mu \mathrm{L})$. Mice injected only with adjuvant were considered as the control-group. At day 35 , independent group of mice were challenged with VTn by intraperitoneal $(10 \mu \mathrm{g}$ in $500 \mu \mathrm{l})$, intranasal once or three time (i.n., $10 \mu \mathrm{g}$ in $50 \mu \mathrm{l}$ ), or by epicutaneous route in anesthetized and previously shaved mice (epi, hypoallergenic dermal tape soaked with $20 \mu \mathrm{g}$ in $200 \mu \mathrm{l}$ was adhered to the scratched back). The low dose of VTn used here (total of $32 \mu \mathrm{g}$ ) was adjusted to prevent death induced by the $\mathrm{LD}_{50}$ of $91 \mu \mathrm{g}$ per animal according to Lopes-Ferreira et al. ${ }^{57}$, and to minimize the extreme discomfort as strong intercostal stretching and shivering hair.

After $48,72,24$, or 48 hours respectively, blood samples were collected by retroorbital bleeding and mice were killed by the injection of lethal dose of sodium pentobarbital anesthesia, and peritoneal fluid, bronchoalveolar lavage fluid (BAL), lung and skin were harvested at various time points, and single cell suspension was prepared. For evaluation the role of platelet-activating factor (PAF) activity in hypersensitivity induced by VTn, fourteen days after the last immunization and 1 hour before i.p. VTn challenge an independent group of BALB/c sensitized-mice was treated by i.p. injection of ABT- 491 at $0.4 \mathrm{mg} / \mathrm{Kg}$ (Sigma-Aldrich).

Assessment of hypersensitivity responses. Symptoms of systemic anaphylaxis induced by VTn appeared within 15 to $30 \mathrm{~min}$ and reached a peak at 40 to $50 \mathrm{~min}$ thereafter. Symptoms were evaluated using 
a scoring system modified slightly according to ${ }^{22}$ and scored as follows: $0=$ no symptoms; $1=$ scratching and rubbing around the nose and head; 2 = puffiness around the eyes and mouth, pilar erecti, reduced activity, and/ or decreased activity with increased respiratory rate; $3=$ wheezing, labored respiration, and cyanosis around the mouth and the tail; $4=$ no activity after prodding or tremor and convulsion; and $5=$ death.

Determination of histamine levels. After VTn challenge (i.p. or i.n.) peritoneal and bronchoalveolar lavage fluid were collected and prepared for sample acylation. Histamine levels were determined by using an enzyme immunoassay kit (59221, IBL, Hamburg, Germany) based on the competition principle, as described by the manufacturer. Determinations of sample were achieved by comparing their absorbance with a reference curve prepared with known calibration concentrations. Detection limit was $1.3 \mathrm{ng} / \mathrm{mL}$.

SDS-PAGE and western blotting. The proteins $(10 \mu \mathrm{g})$ of $T$. nattereri venom were analyzed by SDS-PAGE $12 \%$ under non-reducing conditions. After running, proteins were visualized by staining with Silver. After SDS-PAGE, proteins were identified by transferring the proteins to a nitrocellulose membrane (pore size $=0.2 \mu \mathrm{m}$, Schleicher \& Schüll, Dassel, Germany) and detecting them by immunostaining with plasma from VTn-sensitized mice (1:20 dilution, pool of all challenged-mice) and from seven T. nattereri human victims of both sexes followed by goat peroxidase-labeled anti-mouse or anti-human $\operatorname{IgG}(\mathrm{H}+\mathrm{L})(1: 2,000$ dilution), respectively as a secondary Abs.

Titration of IgG1, IgG2a and IgE by ELISA. Plasma were tested for IgG1 or IgG2a Abs using VTn-coated 96-well plates and biotinylated goat anti-mouse IgG1 or IgG2a antiserum. The reactions were developed with streptavidin-horseradish peroxidase complex (Sigma Chemical Co. St. Louis, Mo, USA), O-phenylenediamine (OPD) and $\mathrm{H}_{2} \mathrm{O}_{2}$ and the plates were read at $490 \mathrm{~nm}$ on an automated ELISA reader (Spectramax, Molecular Devices). Samples were quantified by comparison with a standard curves.

Evaluation of anaphylactic IgG1 and IgE by passive cutaneous anaphylaxis (PCA). The anaphylactic activity of IgG1 was evaluated by PCA reactions in mice previously shaved and injected intradermically $(50 \mu \mathrm{L})$ with three serial dilutions of plasma (inactivated for $1 \mathrm{~h}$ at $56^{\circ} \mathrm{C}$ ) in each side of the dorsal skin. For IgE titration, PCA reactions were performed in rats using non-inactivated plasma. After 2 or $18 \mathrm{~h}$ they were challenged i.v. with 50 or $100 \mu$ of VTn $+0.25 \%$ of Evans blue solution. Extravasation of Evans blue dye, due to increased blood vessel permeability during the first $30 \mathrm{~min}$ of the PCA reactions is dependent mainly on histamine and serotonin released from activated mast cells. All tests were made in triplicate and PCA titers were expressed as the reciprocal of the highest dilution that gave a lesion of $>5 \mathrm{~mm}$ in diameter. The detection threshold of the technique was established at 1:5 dilutions.

Peritoneal cell suspension collection. At time points indicated after VTn challenge, mice were killed, and peritoneal cavity exudates were harvested with $2 \times 2.5 \mathrm{ml}$ of cold PBS $+10 \mathrm{mM}$ EDTA for cell suspensions that were centrifuged at $1500 \mathrm{rpm}$ for $10 \mathrm{~min}$ at $4{ }^{\circ} \mathrm{C}$. Supernatants were stored at $-20^{\circ} \mathrm{C}$ for cytokine determination by ELISA; and cell pellets were resuspended in $1 \mathrm{ml}$ of PBS $+0.1 \%$ BSA. The total leukocyte count was performed and aliquots containing $100 \mu \mathrm{l}$ of cell suspension were applied on glass slides, subjected to centrifugation at $1000 \mathrm{rpm}$ for $10 \mathrm{~min}$ with Cytospin, stained with kit Diff-Quick Stain Set, and analyzed in an optical microscope a $40 \times$ objective. For differential cell counts, 300 leukocytes were classified as mononuclear cells or polymorphonuclear neutrophils/eosinophils and counted, based on staining and morphological characteristics, using a light microscope Axio Imager A1 (Carl Zeiss, Germany) with an AxioCam ICc1 digital camera (Carl Zeiss).

Quantification of cytokines by ELISA. Cytokines were measured in the supernatants of peritoneal exudates after VTn-challenge by a specific two-site sandwich ELISA using antibody pairs purchased from Pharmingen (BD, San Diego, CA, USA). Binding of biotinylated monoclonal antibodies was detected using streptoavidin-horseradish peroxidase complex (Amersham Int., Amersham, UK) and 2-2'-azino-bis (3-ethylbenz-thiazoline-6-sulfonic acid) (Sigma) in $0.1 \mathrm{M}$ citrate buffer containing hydrogen peroxide. Samples were quantified by comparison with standard curves of recombinant mouse cytokines. Detection limits were $3.9 \mathrm{ng} / \mathrm{mL}$ for IL-4, $4.21 \mathrm{ng} / \mathrm{mL}$ for IL-5, $1.21 \mathrm{pg} / \mathrm{mL}$ for IL-17A, $2.56 \mathrm{ng} / \mathrm{mL}$ for IFN- $\gamma$, and $1.71 \mathrm{ng} / \mathrm{mL}$ for eotaxin.

BAL fluid and lung tissue collection. After the last challenge with VTn, mice were killed by the injection of lethal dose of sodium pentobarbital anesthesia and the tracheas were cannulated. The airway lumina was washed with $4 \times 0.5 \mathrm{~mL}$ of Hank's balanced salt solution (HBSS, Gibco BRL, Grand Island, NY) $+10 \mathrm{mM}$ ethylenediaminetetraacetic acid (EDTA). The resulting BAL fluids were immediately centrifuged at $800 \mathrm{rpm}, 4^{\circ} \mathrm{C}$, for $10 \mathrm{~min}$. The supernatant was removed and kept at $-20^{\circ} \mathrm{C}$. Three sections of lung were dissociated into single cell suspensions by mechanical disruption in Gentle MACS dissociator (Miltenyi). Cells were isolated and restimulated for $16 \mathrm{~h}$ at $37^{\circ} \mathrm{C}, 5 \% \mathrm{CO}_{2}$ with a cell stimulation cocktail containing PMA at $20 \mathrm{ng} / \mathrm{mL}$ and ionomycin at $1 \mu \mathrm{M}$ in the presence of brefeldin A and monesin at $10 \mu \mathrm{g} / \mathrm{mL}$. Subsequently, after washing and fixation, cells as $\mathrm{CD} 4^{\text {pos }} \mathrm{T}$ cells were assessed for intracellular content of IFN- $\gamma$, IL-17A, IL-4, IL-5 by flow cytometer using a FACSCalibur flow cytometer equipped with CellQuest software (BD Biosciences) and were analyzed using CellQuest Software (Becton-Dickinson, San Jose, CA).

Histological analysis of lungs. After BAL collection, the lung lobes were washed once with ice-cold HBSS then fixed ( $10 \%$ formaldehyde) and paraffin-embedded. Paraffin-embedded sections $(5 \mu \mathrm{m})$ were stained with hematoxilin/eosin $(\mathrm{H} \& \mathrm{E})$ to evaluate general morphology. All slides were examined with light microscopy at a 
magnification of $\times 10$ or 40 (Axio Imager A1, Carl Zeiss, Germany) calibrated with a reference micrometer slide. For each group of five mice, four stained lung sections from each mouse were analyzed.

Skin and draining lymph nodes collection. In the epicutaneous challenge-mice, the lymph nodes were collected, cells were isolated and re-stimulated for $16 \mathrm{~h}$ at $37^{\circ} \mathrm{C}, 5 \% \mathrm{CO}_{2}$ with a cell stimulation cocktail containing PMA at $20 \mathrm{ng} / \mathrm{mL}$ and ionomycin at $1 \mu \mathrm{M}$ in the presence of brefeldin $\mathrm{A}$ and monesin at $10 \mu \mathrm{g} / \mathrm{mL}$. Subsequently, after washing and fixation, cells as CD4 $4^{\text {pos }} \mathrm{T}$ cells were assessed for intracellular content of IFN- $\gamma$, IL-17A, IL-4, IL-5 by flow cytometer using a FACSCalibur flow cytometer equipped with CellQuest software (BD Biosciences) and were analyzed using CellQuest Software (Becton-Dickinson, San Jose, CA). The skin tissue removed was immediately fixed in $10 \%$ buffered formalin. The tissue was then processed and embedded in paraffin. Five-micrometer tissue sections were prepared and stained using H\&E and toluidine blue methods. The stained paraffin-embedded sections were examined and qualitatively evaluated using light photomicroscopy for inflammatory cell influx. All slides were examined with light microscopy at a magnification of $10 x$ or $40 \times$ (Axio Imager A1; Carl Zeiss) calibrated with a reference micrometer slide. The quantification of the number of cells in a section of $400 \mathrm{~mm}^{2}$ per slide was done using Axio Vision Rel 4.8 software.

Statistical analysis. All values were expressed as mean \pm SEM. Parametric data were evaluated using analysis of variance, followed by the Bonferroni test for multiple comparisons. Non-parametric data were assessed using the Mann-Whitney test. Differences were considered statistically significant at $p<0.05$. The GraphPad Prisma 6 (Graph Pad Software, v6.02, 2013) statistical package was employed.

Ethical statement. Fish were collected according to the Brazilian Environmental Agency (IBAMA Instituto Brasileiro do Meio Ambiente e dos Recursos Naturais Renováveis) under the license number 14693-1.

Female Balb/c mice (5-6 weeks old) were obtained from a colony at the Butantan Institute, São Paulo, Brazil. Animals were housed in a laminar flow holding unit (Gelman Sciences, Sydney, Australia) on autoclaved bedding, in autoclaved cages, in an air-conditioned room under a $12 \mathrm{~h}$ light/dark cycle. Irradiated food and acidified water were provided ad libitum. All procedures involving animals were in accordance with the guidelines provided by the Brazilian College of Animal Experimentation (552/08 and 60/70/02).

Received: 20 February 2019; Accepted: 5 December 2019;

Published online: 17 January 2020

\section{References}

1. Portier, F. \& Richet, C. Action anaphylachque dês quelques venins. CR. Soc. Biol. 54, 170-172 (1902)

2. Ziegman, R. \& Alewood, P. Bioactive components in fish venoms. Toxins (Basel). 30(7(5)), 1497-1531 (2015).

3. Haddad, V. Jr., Lupi, O., Lonza, J. P. \& Tyring, S. K. Tropical dermatology: marine and aquatic dermatology. J. Am. Acad. Dermatol. 61(5), 733-750; quiz 751-752 (2009).

4. Almeida, V. G. \& Rocha, C. M. Registros de acidentes com peixes peçonhentos e/ou venenosos. Rev. Soc. Bras. Toxicol. 7, 26-30 (1989).

5. Auto, H.F. Acidentes por peixes peçonhentos Thalassophryne (Niquim), considerações em torno de 32 casos. Revista da Escola de Ciências Médicas de Alagoas. 34-40 (1992).

6. Facó, P. E. et al. Epidemiologia dos acidentes por Thalassophryne nattereri (niquim) no Estado do Ceará (1992-2002). Revista da Sociedade Brasileira de Medicina Tropical. 38(6), 479-482 (2005).

7. Haddad, V. Jr., Pardal, P. P. O., Cardoso, J. L. \& Martins, I. A. The venomous toadfish Thalassophryne nattereri (niquim or miquim): Repor of 43 injuries provoked in fishermen of Salinópolis (Pará State) and Aracaju (Serjipe State). Rev. Inst. Med. Trop. 4, 221-223 (2003).

8. Lopes-Ferreira, M., Grund, L. Z. \& Lima, C. Thalassophryne nattereri fish venom: from the envenoming to the understanding of the immune system. J. Venom Anim. Toxins Incl. Trop. Dis. 13(20), 35 (2014).

9. Fonseca, L. A. \& Lopes-Ferreira, M. Clinical and experimental studies regarding poisoning caused by a fish T. nattereri (niquim). Ann. Bras. Dermatol. 75, 435-443 (2000).

10. Piran-Soares, A. A. et al. Neutralizing antibodies obtained in a persistent immune response are effective against deleterious effects induced by the Thalassophryne nattereri fish venom. Toxicon. 49, 920-930 (2007).

11. Lopes-Ferreira, M. et al. Hemostatic effects induced by T. nattereri fish venom: a model of endothelium-mediated blood flow impairement. Toxicon. 40, 1141-1147 (2002)

12. Lopes-Ferreira, M. et al. Skeletal muscle necrosis and regeneration after injection of Thalassophryne nattereri (niquim) fish venom in mice. Int. J. Exp. Pathol. 82, 55-64 (2001).

13. Lima, C. et al. Characterization of local inflammatory response induced by Thalassophryne nattereri fish venom in a mouse model of tissue injury. Toxicon. 42, 499-507 (2003).

14. Grund, L. Z., Souza, V. M. O., Faquim-Mauro, E. L., Lima, C. \& Lopes-Ferreira, M. Experimental immunization with Thalassophryne nattereri fish venom: striking IL-5 production and impaired of B220+ cells. Toxicon. 48(5), 499-508 (2006).

15. Grund, L. Z., Komegae, E. N., Lopes-Ferreira, M. \& Lima, C. IL-5 and IL-17A are critical for the chronic IgE response and differentiation of long-lived antibody-secreting cells in inflamed tissues. Cytokine. 59(2), 335-351 (2012).

16. Grund, L. Z., Lopes-Ferreira, M. \& Lima, C. The hierarchical process of differentiation of long-lived antibody-secreting cells is dependent on integrated signals derived from antigen and IL-17A. PLoS One. 18(8(9)), e74566 (2013).

17. Lopes-Ferreira, M. et al. Kininogenase activity of Thalassophryne nattereri fish venom. Biochem. Pharmacol. 68, 2151-2157 (2004).

18. Magalhães, G. S. et al. Natterins, a new class of protein with kininogenase activity characterized from Thalassophryne nattereri fish venom. Biochimie. 87, 687-699 (2005).

19. Komegae, E. N., Grund, L. Z., Lopes-Ferreira, M. \& Lima, C. The longevity of th 2 humoral response induced by proteases natterins requires the participation of long-lasting innate-like B cells and plasma cells in spleen. PLoS One. 28(8(6)), 67135 (2013).

20. Kweon, M. N., Yamamoto, M., Kajiki, M., Takahashi, I. \& Kiyono, H. Systemically derived large intestinal CD4(+) Th2 cells play a central role in STAT6-mediated allergic diarrhea. J. Clin. Invest. 106, 199-206 (2000).

21. Balbino, B. et al. Pathways of immediate hypothermia and leukocyte infiltration in an adjuvant-free mouse model of anaphylaxis. J. Allergy Clin. Immunol. 139(2), 584-596 (2017).

22. Li, X. M., Schofield, B. H., Huang, C. K., Kleiner, G. I. \& Sampson, H. A. A murine model of IgE-mediated cow's milk hypersensitivity. J. Allergy Clin. Immunol. 103, 206-214 (1999). 
23. Capobianco, F. et al. Oral sensitization with shrimp tropomyosin induces in mice allergen-specific IgE, $\mathrm{T}$ cell response and systemic anaphylactic reactions. Int. Immunol. 20(8), 1077-1086 (2008).

24. Hsieh, K. Y., Tsai, C. C., Wu, C. H. \& Lin, R. H. Epicutaneous exposure to protein antigen and food allergy. Clin. Exp. Allergy. 33, 1067-1075 (2003).

25. Arizmendi, N. G. et al. Mucosal exposure to cockroach extract induces allergic sensitization and allergic airway inflammation. Allergy Asthma Clin. Immunol. 14(7(1)), 22-32 (2011).

26. Leung, P. S. et al. Induction of shrimp tropomyosin-specific hypersensitivity in mice. Int. Arch. Allergy Immunol. 147(4), 305-314 (2008).

27. $\mathrm{Li}, \mathrm{X}$. M. et al. A murine model of peanut anaphylaxis: $\mathrm{T}$ - and $\mathrm{B}$-cell responses to a major peanut allergen mimic human responses. J. Allergy Clin. Immunol. 106(1 Pt 1), 150-158 (2000).

28. Gilfillan, A. M. \& Tkaczyk, C. Integrated signalling pathways for mast-cell activation. Nature Rev. Immunol. 6, 218-230 (2006).

29. Arias, K. et al. Concurrent blockade of platelet-activating factor and histamine prevents life-threatening peanut-induced anaphylactic reactions. J. Allergy Clin. Immunol. 124(2), 307-314 (2009).

30. Harada, M. et al. Age-dependent difference in susceptibility to IgE antibody- and IgG1 antibody-mediated passive anaphylactic shock in the mouse. Immunol. Invest. 5-6, 515-523 (1991).

31. Miyajima, I. et al. Systemic anaphylaxis in the mouse can be mediated largely through IgG1 and Fo $\gamma$ RIII. J. Clin. Invest. 99, 901-914 (1997).

32. Finkelman, F. D. Anaphylaxis: lessons from mouse models. J. Allergy Clin. Immunol. 3, 506-515 (2007).

33. Kikuchi, Y. et al. Crucial commitment of proteolytic activity of a purified recombinant major house dust mite allergen Der p1 to sensitization toward IgE and IgG responses. J. Immunol. 177, 1609-1617 (2006).

34. Gough, L., Schulz, O., Sewell, H. F. \& Shakib, F. The cysteine protease activity of the major dust mite allergen Der p 1 selectively enhances the immunoglobulin E antibody response. J. Exp. Med. 190, 1897-1902 (1999).

35. Kauffman, H. F., Tomee, J. F., van de Riet, M. A., Timmerman, A. J. \& Borger, P. Protease-dependent activation of epithelial cells by fungal allergens leads to morphologic changes and cytokine production. J. Allergy Clin. Immunol. 105, 1185-1193 (2000).

36. Gough, L., Campbell, E., Bayley, D., Van Heeke, G. \& Shakib, F. Proteolytic activity of the house dust mite allergen Der p 1 enhances allergenicity in a mouse inhalation model. Clin. Exp. Allergy. 33, 1159-1163 (2003).

37. Lewkowich, I. P. et al. Protease-activated receptor 2 activation of myeloid dendritic cells regulates allergic airway inflammation. Respir. Res. 21, 12-22 (2011).

38. Chen, J. C. et al. The protease allergen Pen c 13 induces allergic airway inflammation and changes in epithelial barrier integrity and function in a murine model. J. Biol. Chem. 286(30), 26667-26679 (2011).

39. Galli, S. J., Tsai, M. \& Piliponsky, A. M. The development of allergic inflammation. Nature. 24(454(7203)), 445-454 (2008).

40. Meijer, M., Rijkers, G. T. \& van Overveld, F. J. Neutrophils and emerging targets for treatment in chronic obstructive pulmonary disease. Exp. Rev. Clin. Immunol. 9, 1055-1068 (2013).

41. Allinne, J. et al. IL-33 blockade affects mediators of persistence and exacerbation in a model of chronic airway inflammation. $J$. Allergy Clin. Immunol. 25, pii: S0091-6749(19)31243-6 (2019).

42. Mould, A. W., Matthaei, K. I., Young, I. G. \& Foster, P. S. Relationship between interleukin-5 and eotaxin in regulating blood and tissue eosinophilia in mice. J. Clin. Invest. 99, 1064-1071 (1997).

43. Sergejeva, S., Ivanov, S., Lotvall, J. \& Linden, A. Interleukin-17 as a recruitment and survival factor for airway macrophages in allergic airway inflammation. Am. J. Respir. Cell Mol. Biol. 33(3), 248-253 (2005).

44. Wang, Y. H. et al. A novel subset of $\mathrm{CD} 4(+) \mathrm{T}(\mathrm{H}) 2$ memory/effector cells that produce inflammatory IL-17 cytokine and promote the exacerbation of chronic allergic asthma. J. Exp. Med. 25(207(11)), 2479-2491 (2010).

45. Palframan, R. T., Collins, P. D., Willhians, T. J. \& Rankin, S. M. Eotaxin induces a rapid release of eosinophils and their progenitors from the bone marrow. Blood. 91, 2240-2248 (1998).

46. Nieuwenhuizen, N., Herbert, D. R., Brombacher, F. \& Lopata, A. L. Differential requirements for interleukin (IL)-4 and IL-13 in protein contact dermatitis induced by Anisakis. Allergy. 64(9), 1309-1318 (2009).

47. Sicherer, S. H. \& Leung, D. Y. 2011. Advances in allergic skin disease, anaphylaxis, and hypersensitivity reactions to foods, drugs, and insects. J. Allergy Clin. Immunol. 127(2), 326-335 (2010).

48. Bonadonna, P., Zanotti, R. \& Müller, U. Mastocytosis and insect venom allergy. Curr. Opin. Allergy Clin. Immunol. 10(4), 347-353 (2010).

49. Gupta, K. \& Harvima, I. T. Mast cell-neural interactions contribute to pain and itch. Immunol. Rev. 282(1), 168-187 (2018).

50. Berton, M. T. \& Linehan, L. A. IL-4 activates a latent DNA-binding factor that binds a shared IFN-g and IL-4 response element present in the germ-line g1 Ig promoter. J. Immunol. 154, 4513-4525 (1995).

51. Zhu, J., Yamane, H., Cote-Sierra, J., Guo, L. \& Paul, W. E. GATA-3 promotes Th2 responses through three different mechanisms: induction of Th2 cytokine production, selective growth of Th2 cells and inhibition of Th1 cell-specific factors. Cell Res. 16(1), 3-10 (2006).

52. Szabo, S. J. et al. A novel transcription factor, T-bet, directs Th1 lineage commitment. Cell. 100, 655-669 (2000).

53. Kuipers, H. et al. Dendritic cells retrovirally overexpressing IL-12 induce strong Th1 responses to inhaled antigen in the lung but fail to revert established Th2 sensitization. J. Leuk. Biol. 5, 1028-1038 (2004).

54. Meyts, I. et al. IL-12 contributes to allergen-induced airway inflammation in experimental asthma. J. Immunol. 177(9), 6460-6470 (2006).

55. Piancatelli, D., Bellotta, L., Del Beato, T., Duse, M. \& Della Penna, M. R. Total IL-12 levels are increased in paediatric atopic dermatitis: correlations with age and disease severity. Int. J. Immunopathol. Pharmacol. 21(2), 359-365 (2008).

56. Zhang, H. et al. Modulation of mast cell proteinase-activated receptor expression and IL-4 release by IL-12. Immunol. Cell Biol. 7, 558-566 (2007).

57. Lopes-Ferreira, M., Barbaro, K. C., Cardoso, D. F., Moura-da-Silva, A. M. \& Mota, I. Thalassophryne nattereri fish venom: biological and biochemical characterization and serum neutralization of its toxic activities. Toxicon. 36, 405-410 (1998).

\section{Acknowledgements}

This study was supported by research grants from São Paulo Research Foundation-Fapesp (08/56700-2 and 10/15913-3) and CNPq.

\section{Author contributions}

Fernanda Miriane Bruni, Erica Maria Martins Coutinho, Aline Ingrid Andrade-Barros and Lidiane Zito Grund: conceived and designed the experiments, performed the experiments and analyzed the data. Monica LopesFerreira and Carla Lima: contributed reagents/materials/analysis tools, conceived and designed the experiments, analyzed the data, and wrote the paper.

\section{Competing interests}

The authors declare no competing interests. 
Additional information

Correspondence and requests for materials should be addressed to C.L.

Reprints and permissions information is available at www.nature.com/reprints.

Publisher's note Springer Nature remains neutral with regard to jurisdictional claims in published maps and institutional affiliations.

(c) (i) Open Access This article is licensed under a Creative Commons Attribution 4.0 International License, which permits use, sharing, adaptation, distribution and reproduction in any medium or format, as long as you give appropriate credit to the original author(s) and the source, provide a link to the Creative Commons license, and indicate if changes were made. The images or other third party material in this article are included in the article's Creative Commons license, unless indicated otherwise in a credit line to the material. If material is not included in the article's Creative Commons license and your intended use is not permitted by statutory regulation or exceeds the permitted use, you will need to obtain permission directly from the copyright holder. To view a copy of this license, visit http://creativecommons.org/licenses/by/4.0/.

(C) The Author(s) 2020 